\title{
Urinary excretion of amino acids and their advanced glycation end-products (AGEs) in adult kidney transplant recipients with emphasis on lysine: furosine excretion is associated with cardiovascular and all-cause mortality
}

\author{
Svetlana Baskal ${ }^{1} \cdot$ Adrian Post $^{2} \cdot$ Daan Kremer $^{2} \cdot$ Alexander Bollenbach $^{1} \cdot$ Stephan J. L. Bakker $^{2} \cdot$ Dimitrios Tsikas $^{1}$ (D
}

Received: 23 July 2021 / Accepted: 8 October 2021 / Published online: 24 October 2021

(c) The Author(s) 2021

\begin{abstract}
Arginine (Arg) and lysine (Lys) moieties of proteins undergo various post-translational modifications (PTM) including enzymatic $N^{\mathrm{G}}$ - and $N^{\varepsilon}$-methylation and non-enzymatic $N^{\mathrm{G}}$ - and $N^{\varepsilon}$-glycation. In a large cohort of stable kidney transplant recipients (KTR, $n=686$ ), high plasma and low urinary concentrations of asymmetric dimethylarginine (ADMA), an abundant PTM metabolite of Arg, were associated with cardiovascular and all-cause mortality. Thus, the prediction of the same biomarker regarding mortality may depend on the biological sample. In another large cohort of stable KTR $(n=555)$, higher plasma concentrations of $N^{\varepsilon}$-carboxymethyl-lysine (CML) and $N^{\varepsilon}$-carboxyethyl-lysine (CEL), two advanced glycation end-products (AGEs) of Lys, were associated with higher cardiovascular mortality. Yet, the associations of urinary AGEs with mortality are unknown. In the present study, we measured $24 \mathrm{~h}$ urinary excretion of Lys, CML, and furosine in $630 \mathrm{KTR}$ and 41 healthy kidney donors before and after donation. Our result indicate that lower urinary CML and lower furosine excretion rates are associated with higher mortality in KTR, thus resembling the associations of ADMA. Lower furosine excretion rates were also associated with higher cardiovascular mortality. The $24 \mathrm{~h}$ urinary excretion rate of amino acids and their metabolites decreased post-donation (varying as little as $-24 \%$ for CEL, and as much as $-62 \%$ for ADMA). For most amino acids, the excretion rate was lower in KTR than in donors pre-donation [except for $S$-(1-carboxyethyl)-L-cysteine (CEC) and $N^{\mathrm{G}}$ carboxyethylarginine (CEA)]. Simultaneous GC-MS measurement of free amino acids, their PTM metabolites and AGEs in urine is a non-invasive approach in kidney transplantation.
\end{abstract}

Keywords AGEs $\cdot$ Cardiovascular risk $\cdot$ Glycation $\cdot$ Kidney $\cdot$ Mortality $\cdot$ Post-translational modification $\cdot$ Transplantation

\begin{tabular}{|c|c|c|c|c|}
\hline \multicolumn{3}{|c|}{ Abbreviations } & CEA & $N^{\mathrm{G}}$-Carboxyethylarginine \\
\hline \multirow{2}{*}{\multicolumn{2}{|c|}{$\begin{array}{l}\text { AGEs } \\
\text { AGE-BSA }\end{array}$}} & Advanced glycation end-products & CEC & $S$-(1-Carboxyethyl)-L-cysteine \\
\hline & & AGEs of bovine serum albumin & CEL & $N^{6}$-Carboxyethyl-L-lysine \\
\hline \multicolumn{2}{|c|}{ BMI } & Body mass index & $\mathrm{CI}$ & Confidence interval \\
\hline \multicolumn{2}{|c|}{ BSA } & Body surface area or bovine serum albumin & CMC & $S$-Carboxymethyl-L-cysteine \\
\hline \multicolumn{3}{|c|}{ CAD } & CML & $N^{6}$-Carboxymethyl-L-lysine \\
\hline & & & CVD & Cardiovascular disease \\
\hline & & & DML & $N^{6}$-Dimethyl-L-lysine \\
\hline \multicolumn{3}{|c|}{ Handling editor: G. J. Peters. } & GC-MS & Gas chromatography-mass spectrometry \\
\hline \multirow{3}{*}{$\triangle$} & \multirow{2}{*}{\multicolumn{2}{|c|}{$\begin{array}{l}\text { Dimitrios Tsikas } \\
\text { Tsikas.Dimitros@mh-hannover.de }\end{array}$}} & GO & Glyoxal \\
\hline & & & HR & Hazard ratio \\
\hline & & & IQR & Interquartile range \\
\hline \multirow[t]{2}{*}{1} & Core Uni & roteomics, Institute of Toxicology, Hannover & KTR & Kidney transplant recipients \\
\hline & $\begin{array}{l}\text { Medical } \\
\text { Germany }\end{array}$ & ool, Carl-Neuberg-Strasse 1, 30625 Hannover, & LC-MS/MS & $\begin{array}{l}\text { Liquid chromatography-tandem mass } \\
\text { spectrometry }\end{array}$ \\
\hline \multirow[t]{2}{*}{2} & Division & Nephrology, Department of Internal Medicine, & MACE & Major adverse cardiovascular events \\
\hline & $\begin{array}{l}\text { Universit } \\
\text { of Gronil }\end{array}$ & $\begin{array}{l}\text { Aedical Center Groningen and University } \\
\mathrm{n}, \text { Groningen, The Netherlands }\end{array}$ & MGO & Methylglyoxal \\
\hline
\end{tabular}




$\begin{array}{ll}\text { MML } & N^{6} \text {-Monomethyl-L-lysine } \\ m / z & \text { Mass-to-charge ratio } \\ \text { PKMT } & \text { Protein-lysine methyltransferase } \\ \text { PTM } & \text { Post-translational modification } \\ \text { RAGE } & \text { Receptor of AGEs } \\ \text { mRAGE } & \text { Membrane-bound RAGE } \\ \text { sRAGE } & \text { Soluble RAGE } \\ \text { TML } & N^{6} \text {-Trimethyl-L-lysine }\end{array}$

\section{Introduction}

Amino acid residues in proteins undergo numerous enzymatic (e.g., citrullination and methylation) and non-enzymatic (e.g., glycation) post-translational modifications (PTMs). PTMs do not only alter the inherent biological activity of the native proteins, but may also be the origin of biologically active metabolites involved in renal and cardiovascular diseases (CVD). In proteins, the terminal guanidine $\left(N^{\mathrm{G}}\right)$ group of L-arginine (Arg), the terminal amine $\left(N^{\varepsilon}\right.$ or $N^{6}$ ) group of L-lysine (Lys), and the sulfhydryl (SH) group of L-cysteine (Cys) react with chemically reactive carbonyl groups such as those of reducing sugars (e.g., glucose, fructose, pentose) to form intermediate reaction products. The so-called early-stage products or Amadori products, such as hemoglobin $\mathrm{A}_{1 \mathrm{c}}\left(\mathrm{HbA}_{1 \mathrm{c}}\right)$, which is an established clinical marker for diabetes, can react further to finally form the socalled advanced glycation end-products (AGEs) (Nagai et al. 2014; see also Rabbani and Thornalley 2020; and Sibbersen and Johannsen 2020). AGEs are also formed in vitro during heating of carbohydrate-rich food. AGEs are often measured in blood and sporadically in urine, and in clinical trials they serve as markers for carbohydrate metabolism and protein denaturation (Nagai et al. 2014). The chemical structures of commonly measured AGEs are shown in Scheme 1. They include $N^{6}$-carboxymethyl-L-lysine (CML), $N^{6}$-carboxyethyl-L-lysine (CEL), $S$-carboxymethyl-L-cysteine (CMC), $S$-(1-carboxyethyl)-L-cysteine (CEC), furosine, i.e., the AGE of fructose and Lys, and pentosidine, i.e., the AGE of Lys and Arg.

Pentosidine in plasma and tissue has been early measured in kidney transplantation studies (Hricik et al. 1993, 1996) and has been associated with kidney function in transplant recipients (Slowik-Zylka et al. 2010). Several studies investigated the involvement of certain circulating AGEs and other biomarkers in chronic kidney disease (Busch et al. 2004, 2010; Stein et al. 2003), both in patients after kidney transplantation (Baumann et al. 2008; Crowley et al. 2013; Franke et al. 2003; Hartog et al. 2004, 2005, 2006) and in patients after heart transplantation (Heidland et al. 2004). As AGEs exert

CML<smiles>N[C@@H](CCCCNCC(=O)O)C(=O)O</smiles><smiles>CC(NCCCC[C@H](N)C(=O)O)C(=O)O</smiles>

CEL<smiles>CC(=O)CSC[C@H](N)C(=O)O</smiles><smiles>CC(SC[C@H](N)C(=O)O)C(=O)O</smiles>

CEC<smiles>N[C@@H](CCCCNCC(=O)c1ccco1)C(=O)O</smiles>

Furosine<smiles>N[C@@H](CCCNc1nc2cccnc2[nH]1)C(=O)O</smiles>

Pentosidine

Scheme 1 Chemical structures of selected advanced glycation endproducts (AGEs) of L-lysine, L-cysteine and L-arginine. CML, $N^{6}$-carboxymethyl-L-lysine; CEL, $N^{6}$-carboxyethyl-L-lysine; CMC, $S$-carboxymethyl-L-cysteine; CEC, $S$-(1-carboxyethyl)-L-cysteine; furosine and pentosidine. The red-colored parts indicate the remaining of the glycation agent including glyoxal (in CML and CMC) and methylglyoxal (in CEL and CEC). Blue, black and green color indicates the residues L-lysine, $\mathrm{L}$-cysteine and $\mathrm{L}$-arginine, respectively 
their biological activities via the soluble and membrane-bound receptor of AGEs, sRAGE and mRAGE, respectively, several groups investigated potential mechanisms of their action in renal transplant recipients (Gross et al. 2007; Kalousová et al. 2009; Liu et al. 2015). Life-factors such as smoking (Schiel et al. 2003) and effects of immunosuppressive therapy in kidney transplant recipients (Xu et al. 2017) have been also investigated in this context.

In a study of one of our groups involving 555 stable kidney transplant recipients (KTR), we found that plasma concentrations of CML and CEL were independently associated with long-term risk of cardiovascular mortality (Sotomayor et al. 2019). The plasma CML and CEL concentrations were determined by liquid chromatography-tandem mass spectrometry (LC-MS/MS) to be on average $1.8 \mu \mathrm{M}$ and $1.0 \mu \mathrm{M}$, respectively, i.e., with a molar ratio of $1.8: 1$, indicating $\mathrm{CML}$ as the more abundant AGE in plasma. In another study, involving 681 stable KTR, we determined in plasma and urine samples the concentration of symmetric dimethylarginine (SDMA), asymmetric dimethylarginine (ADMA) and its major metabolite dimethylamine (DMA) as measures of symmetric and asymmetric methylation of Arg residues in proteins, respectively (Frenay et al. 2015a, b; Said et al. 2019a,b; Post et al. 2021). These studies indicated that Arg methylation, an abundant PTM in humans, is differently associated with cardiovascular mortality: higher plasma concentrations of ADMA were associated with a higher cardiovascular risk and mortality, while higher urinary ADMA excretion rates were associated with a lower cardiovascular risk and mortality. These observations indicate that the outcome of studies may depend upon the biological sample, i.e., plasma vs. urine. Similar observations in those KTR were obtained for homoarginine and guanidinoacetate (Kayacelebi et al. 2017; Hanff et al. 2019a), two Arg metabolites formed by the catalytical action of arginine:glycine amidinotransferase (AGAT) (Tsikas and Wu 2015).

The aim of present study was to measure urinary concentrations of several AGEs, including CML, CEL and furosine, and their common precursor Lys, in urine samples of KTR and healthy donors, and to investigate potential associations between AGEs, transplantation outcome and donation of a kidney. To reach this goal, we newly analyzed urine samples for AGEs and amino acids by means of a validated gas chromatography-mass spectrometry (GC-MS) method that uses deuterium-labeled AGEs as internal standards (Baskal et al. 2021a).

\section{Materials and methods}

\section{Design and study population}

For the current study, we used material from a prospective cohort study among stable KTR in Northern Netherlands
(TransplantLines Food and Nutrition Biobank and Cohort Study, Clinicaltrials.gov No NCT02811835), that has been described in detail previously (van den Berg et al. 2012, 2013, 2014). In this study, a total of 705 KTR and 321 living kidney donors participated. All subjects gave their written informed consent and all patients were transplanted at the University Medical Center Groningen (UMCG). The main inclusion criterion was having a renal graft that had been functioning for at least one year. Main exclusion criteria were drug and alcohol abuse, overt congestive heart failure (NYHA 3-4), malignancy (other than cured skin cancer) and an insufficient understanding of the Dutch language. The baseline examination of each participant was performed between November 2008 and March 2011, and participants were followed up until the end of August 2015. The data of 630 KTR were included for statistical analyses. In addition, a convenience sample of 41 healthy kidney donors (51\% females; mean age, 53 years) derived from the same cohort study had both pre- and post-donation data available, and were, therefore, included in the study. The study protocol (METc 2008/186) was approved by the institutional ethical review board of the UMCG and has been conducted in accordance with the declaration of Helsinki. The primary outcome measure of the study was all-cause mortality. Secondary endpoints were cardiovascular mortality and death-censored graft loss (defined as return to dialysis or re-transplantation). The continuous surveillance system of the outpatient program ensured up-to-date information on patient status. Endpoints were recorded until September 2015 by a qualified physician. There was no loss that was due to follow-up for the primary endpoints.

\section{Clinical measurements}

Each participant received written and verbal instructions on how to collect $24 \mathrm{~h}$ urine on the day prior to the visit to the outpatient clinic. Instructions were to start in the evening 2 days before the visit with emptying of the bladder in the toilet and writing down of the time of the voiding. After that, every urinary voiding would be added to a container, which was kept in the refrigerator at approximately $4{ }^{\circ} \mathrm{C}$, until the same time in the evening was reached as the day before. At that time point, the bladder would be emptied again, and this urine would be added to the container, after which further urine collection was stopped. In the next morning, after an overnight fasting period, all participants (included KTR and healthy kidney donors) visited the outpatient clinic. Anthropometric measurements were performed on the same day as blood collection and urine collection was handed over. A strict protocol was followed for the measurements of blood pressure $(\mathrm{mmHg})$ and heart rate with a semi-automatic device (Dinamap ${ }^{\circledR} 1846$, Critikon, Tampa, FL, USA) every minute for the duration of $15 \mathrm{~min}$; the final value was defined 
as the average of the last three values. Detailed descriptions of anthropometric measurements have been described before (van den Berg et al. 2012, 2013, 2014). For routine clinical chemistry assays, heparin plasma was analyzed spectrophotometrically on the same morning using automated and validated routine methods (Roche Diagnostics, Basel, Switzerland).

\section{GC-MS measurement of urinary amino acids, their PTM metabolites and AGEs}

The urine samples were transferred from UMCG frozen on dry ice to the Institute of Toxicology at Hannover Medical School and stored there (at $-20^{\circ} \mathrm{C}$ ) until analyses. Lys and AGEs were measured by GC-MS in $10-\mu \mathrm{L}$ urine aliquots after solvent evaporation to dryness and a two-step derivatization first with methanolic $2 \mathrm{M} \mathrm{HCl}$ and then with pentafluoropropionic anhydride in ethyl acetate as described elsewhere in detail (Baskal et al. 2021a). This method is based on a GC-MS method previously reported for free amino acids in plasma and urine (Hanff et al. 2019b). GC-MS analyses were performed on the model ISQ from ThermoFisher (Dreieich, Germany) in the selected-ion monitoring mode (SIM) as reported in detail elsewhere (Baskal et al. 2021a).

The precision of the method in terms of relative standard deviation (RSD) ranged between $1.73 \%$ and $3.25 \%$. The accuracy of the method in terms of recovery ranged between 109 and $120 \%$ for the AGEs added to a pooled quality control urine sample donated by a healthy volunteer. These data underline the high analytical reliability of the GC-MS method for the urinary AGEs measured in the present study.

\section{Statistical analyses}

Data analyses and computations were performed with SPSS 24.0 software (IBM, Armonk, NY, USA), Stata SE version 15 (StataCorp, College Station, TX, USA), R version 3.5.1 software (The R-Foundation for Statistical Computing), and GraphPad Prism version 5 (GraphPad Software).

Baseline data are presented as means \pm standard deviation for normally distributed data, as medians [interquartile range, IQR] for non-normally distributed data, and as numbers (percentages) for nominal data. A two-sided $P$ value $<0.05$ was considered to indicate statistical significance. In our initial analyses, we aimed to investigate pre- to post-donation changes in urinary excretion rates of Lys, CML and furosine, using Wilcoxon signed rank tests. Second, we aimed to compare the data of kidney donors to data of KTR, using Mann-Whitney $U$ tests. Additionally, baseline characteristics are provided, along with the results of linear regression models adjusted for sex. Variables were $\log _{2}$ transformed if necessary to fulfill the assumptions for linear regression.

Prospective analyses of urinary AGEs excretion were performed for all-cause mortality, cardiovascular mortality and non-cardiovascular mortality. Prospective analyses were performed using uni- and multivariable Cox regression models. Adjustments were made for a priori selected variables, including age, sex, body mass index (BMI), estimated glomerular filtration rate (eGFR), proteinuria, cardiovascular risk factors and transplantation-related factors. Cardiovascular risk factors included total cholesterol, HDL cholesterol, systolic blood pressure, antihypertensive treatment, smoking (current, ex, or never) and type 2 diabetes. Transplantation-related factors were defined as donor type (deceased versus living), dialysis vintage, time between transplantation and baseline, cold ischemia time, calcineurin inhibitor usage, proliferation inhibitor usage, and the number of transplantations up to baseline. Causal pathway analyses were performed in which we adjusted for sodium, potassium, urea, and creatinine excretion. The proportionality of hazards assumption was tested with the Schoenfeld residual test, and was not violated for the associations of urinary AGEs excretion with all-cause mortality, cardiovascular mortality and non-cardiovascular mortality $(P>0.05$ for all). Potential interactions for covariates were assessed by calculating interaction term, $P$ interaction $<0.05$ was considered to indicate significant effect-modification. To visualize the continuous associations of urinary AGEs with all-cause mortality and cardiovascular mortality, urinary AGEs excretion rates were plotted against the risk of all-cause mortality and cardiovascular mortality, respectively.

\section{Results}

\section{Urinary excretion rates of amino acids, their PTM metabolites and AGEs in KTR and healthy kidney donors before and after donation}

The urinary excretion rates ( $\mu \mathrm{mol} / 24 \mathrm{~h}$ ) of amino acids, selected free PTM metabolites, and free AGEs in the healthy donors pre- and post-donation of a kidney and in KTR are summarized in Table S1. This table also summarizes the percentage changes as the result of the kidney donation by the 41 healthy donors. For a comparison, Table $\mathrm{S} 1$ also lists the molar ratios calculated by dividing the median excretion rates of KTR by those of the donors pre-donation (Pre) and post-donation (Post): KTR/Pre, KTR/Post. The molar ratios Post/Pre were calculated to visualize the effect of kidney donation in the donors.

Mean measured glomerular filtration rate (mGFR) was $120 \pm 25 \mathrm{~mL} / \mathrm{min} / 1.73 \mathrm{~m}^{2}$ before donation, and $76 \pm 14 \mathrm{~mL} / \mathrm{min} / 1.73 \mathrm{~m}^{2}$ after donation, indicating a 
considerable drop (-37\%) in the glomerular filtration rate. With the sole exception of CEA $(+11 \%)$, the excretion rates of the other solutes decreased, varying from $-24 \%$ for CEL to $-62 \%$ for ADMA. The mean decrease was $-45 \pm 11 \%$ when considering all amino acids. Lys excretion rate dropped from 117 [81-203] $\mu \mathrm{mol} / 24 \mathrm{~h}$ before donation to $51.3[41-88] \mu \mathrm{mol} / 24 \mathrm{~h}$ after donation $(-56 \%)$. CML excretion rate was 10.6 [6.1-18] $\mu \mathrm{mol} / 24 \mathrm{~h}$ before donation and 7.8 [4.9-11.9] $\mu \mathrm{mol} / 24 \mathrm{~h}$ after donation $(-26 \%)$. Furosine excretion rate was 1.63 [1.21-2.44] $\mu \mathrm{mol} / 24 \mathrm{~h}$ before donation and 0.89 [0.47-1.32] $\mu \mathrm{mol} / 24 \mathrm{~h}$ after donation $(-45 \%)$. The decreases in the excretion rates were all significant $(P<0.01$ for all solutes).

For a comparison, Table $\mathrm{S} 1$ also lists the molar ratios calculated by dividing the median excretion rates in KTR by the median excretion rates in donor post-donation (Post). The urinary excretion rates of amino acids and their metabolites were measured in $630 \mathrm{KTR}$. Their mean age was $53 \pm 13$ years, $263(41.7 \%)$ of the patients were female, the median time after transplantation was 5.1 [1.6-10.9] years, and the mean eGFR was $45 \pm 19 \mathrm{~mL} / \mathrm{min} / 1.73 \mathrm{~m}^{2}$, i.e., lower than in the healthy donors after kidney donation. With exception of sarcosine (i.e., Sarc, methylglycine), CEA and CEC, the KTR/Pre ratio was lower than 1.0 (Table S1). With the sole exception of guanidino acetate (GAA), the KTR/Post ratio was above 1.0. The Post/Pre ratio was lower than 1.0, except for CEA which was 1.11. These changes indicate clear effects of kidney donation on amino acid excretion in the healthy donors.

The baseline characteristics of the KTR cohort are presented in Table 1 (see also Table S2). Median urinary excretion rates were 84 [55-131] $\mu \mathrm{mol} / 24 \mathrm{~h}$ for Lys, 9.2 [6.0-12.2] $\mu \mathrm{mol} / 24 \mathrm{~h}$ for CML, and 0.90 [0.62-1.28] $\mu \mathrm{mol} / 24 \mathrm{~h}$ for furosine. These values are significantly lower when compared to the healthy kidney donors before donation $(P<0.01$ for all). Lys, CML and furosine excretion rates differed significantly between males and females, with lower rates in the latter $(P<0.01$ for all $)$.

Linear regression analyses adjusted for sex are presented in Table 1. Notably, body weight was an important determinant of Lys (St. $\beta$ 0.16; 95\% CI 0.08-0.24, $P<0.001$ ), and to a lesser extent of CML (St. $\beta 0.10 ; 95 \%$ CI $0.02-0.18$, $P=0.011$ ), but not of furosine, and was independent of sex. Additionally, parameters associated with worse kidney function, including cold ischemia time, creatinine, cystatin $\mathrm{C}$ and urea, were all associated with lower Lys, CML and furosine excretion rates, and were independent of sex. In contrast, the associations of Lys, CML and furosine with eGFR and hemoglobin were positive $(P<0.001$ for all). In addition, urinary sodium, urea and creatinine excretions were positively associated with Lys, CML and furosine excretion rates.

The urinary excretion of furosine was inversely associated with the intake of antihypertensive drugs (St. $\beta-0.34$, $P=0.005$ ). To our knowledge, there is no report in the literature on such an association in health and disease. Calcium antagonist use was associated inversely with furosine and positively with Lys excretion rates, while diuretics use was strongly inversely associated with Lys. It is also interesting to note, that furosine excretion rate was inversely associated with nephropathy, while the excretion rate of CML was associated with prednisolone, which is a widely used immunosuppressive in organ transplantations.

\section{Prospective analyses}

During a median follow-up of 5.3 [4.7-6.0] years, 135 (21\%) KTR died, of which $56(41 \%)$ died due to cardiovascular causes, and 79 (59\%) due to non-cardiovascular causes. Univariable and multivariable Cox regression analyses of urinary Lys, CML and furosine excretion with all-cause mortality, cardiovascular mortality and non-cardiovascular mortality are summarized in Tables 2, 3 and in Fig. 1.

No association was found between urinary Lys excretion rate and all-cause mortality, cardiovascular mortality or noncardiovascular mortality. Urinary CML excretion rate was inversely associated with all-cause mortality (Hazard Ratio (HR) per SD increase: 0.77 [0.64-0.94]; $P=0.009)$ and noncardiovascular mortality (HR: 0.74 [0.57-0.95]; $P=0.02$ ). The association of urinary CML excretion rate with all-cause mortality remained significant after adjustment for potential confounders, while the association with non-cardiovascular mortality was lost after adjusting for transplantation-related factors. Urinary furosine excretion rate was inversely associated with all-cause mortality (HR: $0.61[0.48-0.76] ; P<0.001$ ) (Fig. 1), cardiovascular mortality (HR: 0.54 [0.38-0.78]; $P<0.001)$ and non-cardiovascular mortality (HR: 0.66 $[0.50-0.87] ; P=0.003)$. The associations of urinary furosine excretion with all-cause mortality and cardiovascular mortality remained significant after adjustment for potential confounders, while the association with non-cardiovascular mortality was lost after adjusting for eGFR and proteinuria.

Associations of urinary CML and furosine excretion rates with all-cause mortality and cardiovascular mortality in KTR are shown in Fig. 1. Causal pathway analyses demonstrated that the associations of urinary CML and furosine excretion rates with all-cause mortality were lost after adjustment for urinary urea and creatinine excretion, reflecting protein intake and muscle mass, respectively (Table S3). 
Table 1 KTR characteristics at baseline and linear regression analyses for 24-h lysine, CML and furosine urinary excretion rates

\begin{tabular}{|c|c|c|c|c|c|c|c|}
\hline \multirow{4}{*}{$\begin{array}{l}\text { Lysine excretion } \\
(\mu \mathrm{mol} / 24 \mathrm{~h}) \\
\text { CML excretion } \\
(\mu \mathrm{mol} / 24 \mathrm{~h}) \\
\text { Furosine excretion } \\
(\mu \mathrm{mol} / 24 \mathrm{~h})\end{array}$} & \multirow{4}{*}{$\begin{array}{l}n=630 \\
84[55-131] \\
9.2[6.1-12.2] \\
0.9[0.6-1.3]\end{array}$} & \multicolumn{6}{|c|}{ Linear regression analyses, adjusted for sex } \\
\hline & & \multicolumn{2}{|c|}{ Lysine as dependent variable ${ }^{a}$} & \multicolumn{2}{|c|}{ CML as dependent variable ${ }^{\mathrm{a}}$} & \multicolumn{2}{|l|}{$\begin{array}{l}\text { Furosine as dependent } \\
\text { variable }^{\mathrm{a}}\end{array}$} \\
\hline & & & & & & & \\
\hline & & St. $\beta(95 \% \mathrm{CI})$ & $P$ value & St. $\beta(95 \% \mathrm{CI})$ & $P$ value & St. $\beta(95 \% \mathrm{CI})$ & $P$ value \\
\hline \multicolumn{8}{|l|}{ Clinical characteristics } \\
\hline Female sex, $n(\%)^{\mathrm{b}}$ & $263(42)$ & $\begin{array}{l}-0.45(-0.60 \text { to } \\
0.29)\end{array}$ & $<0.001^{\mathrm{c}}$ & $\begin{array}{l}-0.49(-0.64 \text { to } \\
-0.33)\end{array}$ & $<0.001$ & $\begin{array}{l}-0.41(-0.57 \text { to } \\
-0.26)\end{array}$ & $<0.001$ \\
\hline Age, y & $53(13)$ & $\begin{array}{c}-0.11 \\
0.03)\end{array}$ & 0.006 & $\begin{array}{l}-0.02(-0.10 \text { to } \\
0.06)\end{array}$ & 0.6 & $\begin{array}{l}-0.08(-0.16 \text { to } \\
-0.00)\end{array}$ & 0.042 \\
\hline \multicolumn{8}{|l|}{$\begin{array}{l}\text { Primary renal dis- } \\
\text { ease, } n(\%)\end{array}$} \\
\hline Unknown & $93(15)$ & Ref & & Ref & & Ref & \\
\hline Glomerulonephritis & $162(26)$ & $0.03(-0.22$ to 0.28$)$ & 0.8 & $0.07(-0.18$ to 0.32$)$ & 0.6 & $0.06(-0.20$ to 0.30$)$ & 0.7 \\
\hline Interstitial nephritis & $80(13)$ & $0.17(-0.12$ to 0.47$)$ & 0.2 & $0.09(-0.20$ to 0.39$)$ & 0.6 & $0.11(-0.19$ to 0.40$)$ & 0.5 \\
\hline Cystic kidney disease & $131(21)$ & $\begin{array}{l}-0.04 \text { ( }-0.30 \text { to } \\
0.22)\end{array}$ & 0.8 & $0.03(-0.23$ to 0.29$)$ & 0.8 & $\begin{array}{l}-0.09 \text { ( }-0.36 \text { to } \\
0.17)\end{array}$ & 0.5 \\
\hline $\begin{array}{l}\text { Other congenital/ } \\
\text { hereditary disease }\end{array}$ & $34(5)$ & $\begin{array}{l}-0.04(-0.43 \text { to } \\
0.34)\end{array}$ & 0.8 & $\begin{array}{l}-0.10(-0.48 \text { to } \\
0.28)\end{array}$ & 0.6 & $\begin{array}{c}-0.07(-0.45 \text { to } \\
0.32)\end{array}$ & 0.7 \\
\hline $\begin{array}{l}\text { Renal vascular } \\
\text { disease }\end{array}$ & $36(6)$ & $0.37(-0.00$ to 0.75$)$ & 0.053 & $0.26(-0.12$ to 0.63$)$ & 0.2 & $0.06(-0.32$ to 0.43$)$ & 0.8 \\
\hline Diabetic nephropathy & $33(5)$ & $\begin{array}{l}-0.01(-0.39 \text { to } \\
0.38)\end{array}$ & 1.0 & $\begin{array}{l}-0.11(-0.50 \text { to } \\
0.28)\end{array}$ & 0.6 & $\begin{array}{l}-0.46(-0.84 \text { to } \\
-0.07)\end{array}$ & 0.021 \\
\hline $\begin{array}{l}\text { Other multisystem } \\
\text { diseases }\end{array}$ & $44(7)$ & $0.09(-0.26$ to 0.44$)$ & 0.6 & $0.25(-0.10$ to 0.60$)$ & 0.2 & $0.25(-0.10$ to 0.61$)$ & 0.2 \\
\hline Other & $17(3)$ & $0.33(-0.18$ to 0.83$)$ & 0.2 & $0.29(-0.22$ to 0.79$)$ & 0.3 & $0.25(-0.25$ to 0.76$)$ & 0.3 \\
\hline Height, $\mathrm{cm}$ & $174(10)$ & $0.03(-0.08$ to 0.13$)$ & 0.6 & $0.01(-0.09$ to 0.11$)$ & 0.8 & $\begin{array}{l}-0.02(-0.12 \text { to } \\
0.08)\end{array}$ & 0.7 \\
\hline Weight, kg & $81(17)$ & $0.16(0.08-0.24)$ & $<0.001$ & $0.10(0.02-0.18)$ & 0.011 & $0.06(-0.02$ to 0.14$)$ & 0.2 \\
\hline $\begin{array}{l}\text { Body surface area, } \\
\mathrm{m}^{2}\end{array}$ & $1.95(0.22)$ & $0.16(0.07-0.25)$ & $<0.001$ & $0.10(0.02-0.19)$ & 0.021 & $0.05(-0.03$ to 0.14$)$ & 0.2 \\
\hline $\begin{array}{l}\text { Body mass index, } \\
\mathrm{kg} / \mathrm{m}^{2}\end{array}$ & $26.7(4.9)$ & $0.15(0.08-0.23)$ & $<0.001$ & $0.10(0.03-0.18)$ & 0.007 & $0.07(-0.01$ to 0.14$)$ & 0.093 \\
\hline $\begin{array}{l}\text { Systolic blood pres- } \\
\text { sure, } \mathrm{mmHg}\end{array}$ & $136(17)$ & $0.06(-0.02$ to 0.13$)$ & 0.1 & $0.03(-0.05$ to 0.10$)$ & 0.5 & $\begin{array}{l}-0.03(-0.11 \text { to } \\
0.05)\end{array}$ & 0.4 \\
\hline Diabetes, $n(\%)$ & $152(24)$ & $0.10(-0.08$ to 0.28$)$ & 0.3 & $0.17(-0.01$ to 0.35$)$ & 0.058 & $0.05(-0.13$ to 0.23$)$ & 0.6 \\
\hline $\begin{array}{l}\text { History of cardiovas- } \\
\text { cular disease, } n(\%)\end{array}$ & $160(25)$ & $\begin{array}{l}-0.01(-0.19 \text { to } \\
0.17)\end{array}$ & 0.9 & $0.10(-0.08$ to 0.26$)$ & 0.3 & $\begin{array}{l}-0.05(-0.23 \text { to } \\
0.13)\end{array}$ & 0.6 \\
\hline \multicolumn{8}{|l|}{$\begin{array}{l}\text { Smoking status, } n \\
\quad(\%)\end{array}$} \\
\hline Never & $237(40)$ & Ref & & Ref & & Ref & \\
\hline History of smoking & $280(48)$ & $\begin{array}{l}-0.03(-0.20 \text { to } \\
0.14)\end{array}$ & 0.7 & $0.01(-0.16$ to 0.18$)$ & 0.9 & $0.06(-0.11$ to 0.23$)$ & 0.5 \\
\hline Current smoking & $73(12)$ & $\begin{array}{l}-0.14(-0.40 \text { to } \\
0.12)\end{array}$ & 0.3 & $\begin{array}{l}-0.05(-0.31 \text { to } \\
0.21)\end{array}$ & 0.7 & $\begin{array}{l}-0.05(-0.31 \text { to } \\
0.21)\end{array}$ & 0.7 \\
\hline $\begin{array}{l}\text { Pre-emptive trans- } \\
\text { plantation, } n(\%)\end{array}$ & $104(17)$ & $0.05(-0.16$ to 0.26$)$ & 0.6 & $\begin{array}{l}-0.08(-0.29 \text { to } \\
0.12)\end{array}$ & 0.4 & 0.03 ( -0.18 to 0.24$)$ & 0.8 \\
\hline $\begin{array}{l}\text { Duration of dialysis, } \\
\text { months }^{\mathrm{a}}\end{array}$ & $24[4-48]$ & $\begin{array}{l}-0.04(-0.12 \text { to } \\
0.03)\end{array}$ & 0.3 & $0.01(-0.07$ to 0.08$)$ & 0.9 & $\begin{array}{l}-0.03(-0.10 \text { to } \\
0.05)\end{array}$ & 0.5 \\
\hline $\begin{array}{l}\text { Time after transplan- } \\
\text { tation, } \mathrm{y}^{\mathrm{a}}\end{array}$ & $5.1[1.6-10.9]$ & $\begin{array}{l}-0.05(-0.13 \text { to } \\
0.03)\end{array}$ & 0.2 & $\begin{array}{l}-0.02(-0.10 \text { to } \\
0.06)\end{array}$ & 0.6 & $\begin{array}{l}-0.06(-0.13 \text { to } \\
0.02)\end{array}$ & 0.15 \\
\hline
\end{tabular}


Table 1 (continued)

\begin{tabular}{|c|c|c|c|c|c|c|c|}
\hline \multirow{4}{*}{$\begin{array}{l}\text { Lysine excretion } \\
(\mu \mathrm{mol} / 24 \mathrm{~h}) \\
\text { CML excretion } \\
(\mu \mathrm{mol} / 24 \mathrm{~h}) \\
\text { Furosine excretion } \\
(\mu \mathrm{mol} / 24 \mathrm{~h})\end{array}$} & \multirow{4}{*}{$\begin{array}{l}n=630 \\
84[55-131] \\
9.2[6.1-12.2] \\
0.9[0.6-1.3]\end{array}$} & \multicolumn{6}{|c|}{ Linear regression analyses, adjusted for sex } \\
\hline & & \multicolumn{2}{|c|}{ Lysine as dependent variable ${ }^{\mathrm{a}}$} & \multicolumn{2}{|c|}{ CML as dependent variable ${ }^{\mathrm{a}}$} & \multicolumn{2}{|l|}{$\begin{array}{l}\text { Furosine as dependent } \\
\text { variable }^{\mathrm{a}}\end{array}$} \\
\hline & & & & & & & \\
\hline & & St. $\beta(95 \% \mathrm{CI})$ & $P$ value & St. $\beta(95 \% \mathrm{CI})$ & $P$ value & St. $\beta(95 \% \mathrm{CI})$ & $P$ value \\
\hline $\begin{array}{l}\text { History of rejection, } \\
n(\%)\end{array}$ & $161(26)$ & $\begin{array}{l}-0.10(-0.28 \text { to } \\
0.08)\end{array}$ & 0.3 & $\begin{array}{l}-0.11(-0.29 \text { to } \\
0.06)\end{array}$ & 0.2 & $\begin{array}{l}-0.11(-0.28 \text { to } \\
0.07)\end{array}$ & 0.2 \\
\hline $\begin{array}{l}\text { History of delayed } \\
\text { graft function, } n \\
(\%)\end{array}$ & $48(8)$ & $0.04(-0.25$ to 0.33$)$ & 0.8 & $0.07(-0.22$ to 0.36$)$ & 0.6 & $0.10(-0.19$ to 0.38$)$ & 0.5 \\
\hline $\begin{array}{l}\text { Anti-HLA Class II } \\
\text { antibodies, } n(\%)\end{array}$ & $106(17)$ & $\begin{array}{l}-0.09(-0.30 \text { to } \\
0.12)\end{array}$ & 0.4 & $\begin{array}{l}-0.15(-0.35 \text { to } \\
0.06)\end{array}$ & 0.2 & $\begin{array}{l}-0.13(-0.34 \text { to } \\
0.08)\end{array}$ & 0.2 \\
\hline Donor age, $\mathrm{y}$ & $43(15)$ & $\begin{array}{l}-0.04(-0.12 \text { to } \\
0.04)\end{array}$ & 0.3 & $0.01(-0.07$ to 0.08$)$ & 0.9 & $\begin{array}{l}-0.03(-0.10 \text { to } \\
0.05)\end{array}$ & 0.5 \\
\hline Living donor, $n(\%)$ & $221(35)$ & $0.05(-0.11$ to 0.21$)$ & 0.5 & $\begin{array}{l}-0.08(-0.24 \text { to } \\
0.08)\end{array}$ & 0.3 & $0.11(-0.05$ to 0.27$)$ & 0.2 \\
\hline $\begin{array}{l}\text { Cold ischemia time, } \\
\mathrm{h}^{\mathrm{a}}\end{array}$ & $15[2.8-21]$ & $\begin{array}{l}-0.09(-0.17 \text { to } \\
-0.014)\end{array}$ & 0.021 & $\begin{array}{l}-0.01(-0.09 \text { to } \\
0.06)\end{array}$ & 0.7 & $\begin{array}{l}-0.11(-0.18 \text { to } \\
-0.03)\end{array}$ & 0.007 \\
\hline \multicolumn{8}{|c|}{ Laboratory measurements } \\
\hline Hemoglobin, g/dL & $8.2(1.1)$ & $0.16(0.09-0.24)$ & $<0.001$ & $0.18(0.11-0.26)$ & $<0.001$ & $0.22(0.14-0.30)$ & $<0.001$ \\
\hline Sodium mmol/L & $141(2.8)$ & $0.13(0.05-0.20)$ & 0.001 & $0.20(0.14-0.29)$ & $<0.001$ & $0.17(0.09-0.24)$ & $<0.001$ \\
\hline Potassium, mmol/L & $4.0(0.5)$ & $\begin{array}{l}-0.11(-0.19 \text { to } \\
-0.03)\end{array}$ & 0.007 & $\begin{array}{l}-0.05(-0.13 \text { to } \\
0.03)\end{array}$ & 0.2 & $\begin{array}{l}-0.07(-0.15 \text { to } \\
0.01)\end{array}$ & 0.072 \\
\hline Creatinine, $\mu \mathrm{mol} / \mathrm{L}^{\mathrm{a}}$ & $125[100-160]$ & $\begin{array}{l}-0.13(-0.21 \text { to } \\
-0.05)\end{array}$ & 0.001 & $\begin{array}{l}-0.13(-0.21 \text { to } \\
0.05)\end{array}$ & 0.002 & $\begin{array}{l}-0.30(-0.37 \text { to } \\
-0.22)\end{array}$ & $<0.001$ \\
\hline Cystatin C, mg/L & $1.85(0.79)$ & $\begin{array}{l}-0.15(-0.23 \text { to } \\
-0.07)\end{array}$ & $<0.001$ & $\begin{array}{l}-0.11(-0.19 \text { to } \\
-0.03)\end{array}$ & 0.004 & $\begin{array}{l}-0.32(-0.39 \text { to } \\
-0.24)\end{array}$ & $<0.001$ \\
\hline $\begin{array}{l}\mathrm{eGFR}, \mathrm{mL} / \mathrm{min} / 1.73 \\
\mathrm{~m}^{2}\end{array}$ & 45 (19) & $0.21(0.13-0.29)$ & $<0.001$ & $0.13(0.05-0.20)$ & 0.001 & $0.32(0.24-0.39)$ & $<0.001$ \\
\hline Urea, $\mathrm{mmol} / \mathrm{L}^{\mathrm{a}}$ & $9.5[7.2-13.3]$ & $\begin{array}{l}-0.19(-0.26 \text { to } \\
-0.11)\end{array}$ & $<0.001$ & $\begin{array}{l}-0.10(-0.17 \text { to } \\
-0.02)\end{array}$ & 0.012 & $\begin{array}{l}-0.27(-0.34 \text { to } \\
-0.19)\end{array}$ & $<0.001$ \\
\hline $\begin{array}{l}\text { Triglycerides, mmol/ } \\
\mathrm{L}^{\mathrm{a}}\end{array}$ & $1.7[1.3-2.3]$ & $0.02(-0.06$ to 0.10$)$ & 0.6 & $0.04(-0.04$ to 0.11$)$ & 0.4 & $\begin{array}{l}-0.01(-0.09 \text { to } \\
0.07)\end{array}$ & 0.9 \\
\hline $\begin{array}{l}\text { HDL cholesterol, } \\
\mathrm{mmol} / \mathrm{L}^{\mathrm{a}}\end{array}$ & $1.3[1.1-1.6]$ & $\begin{array}{l}-0.04(-0.13 \text { to } \\
0.04)\end{array}$ & 0.3 & $\begin{array}{l}-0.03(-0.11 \text { to } \\
0.06)\end{array}$ & 0.5 & $0.05(-0.03$ to 0.13$)$ & 0.2 \\
\hline $\begin{array}{l}\text { LDL cholesterol, } \\
\mathrm{mmol} / \mathrm{L}\end{array}$ & $2.95(0.92)$ & $0.02(-0.06$ to 0.10$)$ & 0.6 & $0.03(-0.05$ to 0.11$)$ & 0.4 & $0.04(-0.04$ to 0.11$)$ & 0.4 \\
\hline $\mathrm{HbA} 1 \mathrm{c}, \%^{\mathrm{a}}$ & $5.8[5.5-6.2]$ & $0.07(-0.01$ to 0.15$)$ & 0.082 & $0.13(0.06-0.21)$ & 0.001 & $0.08(0.01-0.16)$ & 0.035 \\
\hline $\begin{array}{l}\text { Leukocyte count, } \\
10^{9} / \mathrm{L}\end{array}$ & $8.1(2.6)$ & $0.03(-0.05$ to 0.11$)$ & 0.4 & $0.08(0.00-0.16)$ & 0.038 & $0.03(-0.05$ to 0.11$)$ & 0.5 \\
\hline hs-CRP, mg/L ${ }^{a}$ & $1.6[0.7-4.6]$ & $0.01(-0.07$ to 0.09$)$ & 0.7 & $0.02(-0.06$ to 0.10$)$ & 0.6 & $\begin{array}{l}-0.07(-0.14 \text { to } \\
0.01)\end{array}$ & 0.097 \\
\hline Albumin, g/L & $43.0(3.0)$ & $0.05(-0.03$ to 0.12$)$ & 0.3 & $0.03(-0.05$ to 0.11$)$ & 0.4 & $0.12(0.04-0.20)$ & 0.003 \\
\hline $\begin{array}{l}\text { Urinary protein } \\
\text { excretion, } g / 24 \mathrm{~h}\end{array}$ & $0.40(0.81)$ & $0.07(-0.01$ to 0.14$)$ & 0.091 & $\begin{array}{l}-0.08(-0.16 \text { to } \\
-0.00)\end{array}$ & 0.042 & $\begin{array}{l}-0.12(-0.20 \text { to } \\
-0.04)\end{array}$ & 0.002 \\
\hline $\begin{array}{l}\text { Urinary sodium } \\
\text { excretion, } \\
\mathrm{mmol} / 24 \mathrm{~h}\end{array}$ & $158(63)$ & $0.28(0.20-0.36)$ & $<0.001$ & $0.25(0.18-0.33)$ & $<0.001$ & $0.26(0.18-0.33)$ & $<0.001$ \\
\hline $\begin{array}{l}\text { Urinary urea excre- } \\
\text { tion, } \mathrm{mmol} / 24 \mathrm{~h}\end{array}$ & $392(114)$ & $0.25(0.17-0.33)$ & $<0.001$ & $0.22(0.14-0.30)$ & $<0.001$ & $0.29(0.21-0.37)$ & $<0.001$ \\
\hline $\begin{array}{l}\text { Urinary creati- } \\
\text { nine excretion, } \\
\mathrm{mmol} / 24 \mathrm{~h}\end{array}$ & $11.8(3.5)$ & $0.27(0.18-0.36)$ & $<0.001$ & $0.22(0.13-0.31)$ & $<0.001$ & $0.30(0.21-0.39)$ & $<0.001$ \\
\hline
\end{tabular}


Table 1 (continued)

\begin{tabular}{|c|c|c|c|c|c|c|c|}
\hline \multirow{4}{*}{$\begin{array}{l}\text { Lysine excretion } \\
(\mu \mathrm{mol} / 24 \mathrm{~h}) \\
\text { CML excretion } \\
(\mu \mathrm{mol} / 24 \mathrm{~h}) \\
\text { Furosine excretion } \\
(\mu \mathrm{mol} / 24 \mathrm{~h})\end{array}$} & \multirow{4}{*}{$\begin{array}{l}n=630 \\
84[55-131] \\
9.2[6.1-12.2] \\
0.9[0.6-1.3]\end{array}$} & \multicolumn{6}{|c|}{ Linear regression analyses, adjusted for sex } \\
\hline & & \multicolumn{2}{|c|}{ Lysine as dependent variable ${ }^{\mathrm{a}}$} & \multicolumn{2}{|c|}{ CML as dependent variable ${ }^{a}$} & \multicolumn{2}{|l|}{$\begin{array}{l}\text { Furosine as dependent } \\
\text { variable }^{\mathrm{a}}\end{array}$} \\
\hline & & & & & & & \\
\hline & & St. $\beta(95 \%$ CI $)$ & $P$ value & St. $\beta(95 \%$ CI $)$ & $P$ value & St. $\beta(95 \%$ CI $)$ & $P$ value \\
\hline \multicolumn{8}{|l|}{ Medication } \\
\hline $\begin{array}{l}\text { Angiotensin-2 } \\
\text { antagonist, } n(\%)\end{array}$ & $95(15)$ & $\begin{array}{l}-0.11(-0.32 \text { to } \\
0.11)\end{array}$ & 0.3 & $\begin{array}{l}-0.03(-0.24 \text { to } \\
0.19)\end{array}$ & 0.8 & $\begin{array}{l}-0.09(-0.31 \text { to } \\
0.13)\end{array}$ & 0.4 \\
\hline ACE-inhibitor, $n(\%)$ & $200(32)$ & $\begin{array}{l}-0.04 \text { ( }-0.21 \text { to } \\
0.12)\end{array}$ & 0.6 & $\begin{array}{l}-0.03 \text { ( }-0.19 \text { to } \\
0.14)\end{array}$ & 0.8 & $\begin{array}{l}-0.01(-0.18 \text { to } \\
0.16)\end{array}$ & 0.9 \\
\hline Betablocker, $n(\%)$ & $403(64)$ & $\begin{array}{l}-0.09(-0.25 \text { to } \\
0.07)\end{array}$ & 0.3 & $\begin{array}{l}-0.08(-0.24 \text { to } \\
0.08)\end{array}$ & 0.3 & $\begin{array}{l}-0.02(-0.18 \text { to } \\
0.13)\end{array}$ & 0.8 \\
\hline $\begin{array}{l}\text { Calcium antagonist, } \\
n(\%)\end{array}$ & $154(24)$ & $0.27(0.10-0.45)$ & 0.002 & $0.03(-0.15$ to 0.21$)$ & 0.8 & $\begin{array}{l}-0.18(-0.34 \text { to } \\
-0.02)\end{array}$ & 0.032 \\
\hline Diuretic, $n(\%)$ & $250(40)$ & $\begin{array}{l}-0.26(-0.41 \text { to } \\
-0.10)\end{array}$ & 0.001 & $0.00(-0.15$ to 0.16$)$ & 1.0 & $\begin{array}{l}-0.05(-0.23 \text { to } \\
0.13)\end{array}$ & 0.6 \\
\hline Prednisolone, $n(\%)$ & $627(100)$ & $\begin{array}{l}-0.36(-1.47 \text { to } \\
0.75)\end{array}$ & 0.5 & $1.77(0.68-2.87)$ & 0.002 & $0.33(-0.78$ to 1.45$)$ & 0.6 \\
\hline $\begin{array}{l}\text { Calcineurin inhibitor, } \\
n(\%)\end{array}$ & $359(57)$ & $\begin{array}{l}-0.06(-0.21 \text { to } \\
0.10)\end{array}$ & 0.5 & $\begin{array}{l}-0.03(-0.19 \text { to } \\
0.12)\end{array}$ & 0.7 & $\begin{array}{l}-0.08(-0.24 \text { to } \\
0.07)\end{array}$ & 0.3 \\
\hline $\begin{array}{l}\text { Proliferation inhibi- } \\
\text { tor, } n(\%)\end{array}$ & $537(85)$ & $0.04(-0.18$ to 0.25$)$ & 0.7 & $\begin{array}{l}-0.11(-0.33 \text { to } \\
0.10)\end{array}$ & 0.3 & $0.01(-0.21$ to 0.22$)$ & 1.0 \\
\hline $\begin{array}{l}\text { mTOR inhibitor, } n \\
(\%)\end{array}$ & $20(3)$ & $0.41(-0.03$ to 0.84$)$ & 0.067 & $0.15(-0.28$ to 0.59$)$ & 0.5 & $0.21(-0.23$ to 0.64$)$ & 0.4 \\
\hline
\end{tabular}

Normally distributed data are presented as mean \pm standard deviation, skewed data as median [interquartile range], and categorical data as number (valid percentage)

${ }^{a}$ Variables were $\log _{2}$ transformed to fulfill the assumptions in linear regression analyses

${ }^{\mathrm{b}}$ Linear regression results are derived from a univariable model for sex. Diabetes was defined according to the American Diabetes Association criteria. Data on smoking status was missing in 45 patients (7.1\%), data on donor age was missing in 16 patients $(2.5 \%)$, data on HbA1c were missing in 23 patients $(3.7 \%$ ), and data on hs-CRP were missing in 35 patients (5.6\%). All other variables had missing data for $\leq 10$ patients. $e G F R$ estimated glomerular filtration rate as calculated using the creatinine and cystatin C-based CKD-EPI formula, $h s$ - $C R P$ high-sensitivity C-reactive protein

${ }^{\mathbf{c}}$ Numbers in bold indicate statistical significance

\section{Discussion}

The kidney is a multifunctional organ, with functions depending on and independent of the nephron. About 20\% of the blood volume that enters the kidneys is filtered through the glomerulus. The estimated glomerulus filtration rate (eGFR) is a measure of kidney function. Substances needed by the body (e.g., water, electrolytes, amino acids, glucose) are reabsorbed from the ultrafiltrate by transporters specific for charge-free and charged substances. In kidney failure, eGFR decreases below 15\% and necessitates dialysis and kidney transplantation. Donation of a kidney by a healthy subject is not only a life-saving measure for the patient, but it also concerns the donor's post-donation life as it forces them to live with a single kidney. Beyond these crucially important issues, kidney transplantation is a unique clinical condition to study various aspects of kidney's physiology and pathology. Furthermore, studies aiming to improve kidney transplantation by prolonging survival and improving life post-transplantation are warranted.

Previously, in a cohort of 555 stable KTR (mean eGFR, $47 \mathrm{~mL} / \mathrm{min} / 1.73 \mathrm{~m}^{2}$ ), CML and CEL, two AGEs of Lys, were measured by LC-MS/MS in plasma at mean concentrations of $374 \mathrm{ng} / \mathrm{mL}(1.83 \mu \mathrm{M})$ and $224 \mathrm{ng} / \mathrm{mL}(1.03 \mu \mathrm{M})$, respectively, with a mean CML-to-CEL molar ratio of 1.8. Circulating CML and CEL were found to be independently associated with long-term risk of cardiovascular mortality (Sotomayor et al. 2019). In the present study, we measured by GC-MS in $24 \mathrm{~h}$ collected urine samples of another cohort of $630 \mathrm{KTR}$ (mean eGFR, $45 \mathrm{~mL} / \mathrm{min} / 1.73 \mathrm{~m}^{2}$ ) and in 41 
Table 2 Association of urinary excretion rates of Lys, CML and furosine with all-cause mortality, cardiovascular mortality, and noncardiovascular mortality in KTR

\begin{tabular}{|c|c|c|c|c|c|c|}
\hline & \multicolumn{2}{|l|}{ All-cause mortality } & \multicolumn{2}{|c|}{ Cardiovascular mortality } & \multicolumn{2}{|c|}{$\begin{array}{l}\text { Non-cardiovascular mortal } \\
\text { ity }\end{array}$} \\
\hline & $\begin{array}{l}\text { HR per SD } \\
\text { increase }[95 \% \mathrm{CI}]\end{array}$ & $P$ & $\begin{array}{l}\text { HR per SD } \\
\text { increase }[95 \% \mathrm{CI}]\end{array}$ & $P$ & $\begin{array}{l}\text { HR per SD } \\
\text { increase }[95 \% \mathrm{CI}]\end{array}$ & $P$ \\
\hline \multicolumn{7}{|l|}{ Lysine } \\
\hline Model 1 & $0.79[0.59-1.07]$ & 0.14 & $0.92[0.66-1.28]$ & 0.62 & $0.68[0.42-1.10]$ & 0.11 \\
\hline Model 2 & $0.83[0.62-1.10]$ & 0.20 & $0.90[0.63-1.27]$ & 0.54 & $0.76[0.48-1.19]$ & 0.23 \\
\hline Model 3 & $0.87[0.67-1.12]$ & 0.28 & $0.91[0.65-1.27]$ & 0.57 & $0.83[0.56-1.23]$ & 0.35 \\
\hline Model 4 & $0.87[0.64-1.18]$ & 0.37 & $0.88[0.56-1.40]$ & 0.59 & $0.87[0.58-1.29]$ & 0.48 \\
\hline Model 5 & $0.90[0.70-1.15]$ & 0.40 & $0.94[0.68-1.31]$ & 0.72 & $0.86[0.59-1.25]$ & 0.43 \\
\hline \multicolumn{7}{|l|}{ CML } \\
\hline Model 1 & $0.77[0.64-0.94]$ & 0.009 & $0.82[0.62-1.10]$ & 0.19 & $0.74[0.57-0.95]$ & 0.02 \\
\hline Model 2 & $0.74[0.61-0.91]$ & 0.004 & $0.75[0.56-1.01]$ & 0.06 & $0.73[0.56-0.96]$ & 0.03 \\
\hline Model 3 & $0.78[0.64-0.96]$ & 0.02 & $0.76[0.56-1.04]$ & 0.09 & $0.80[0.61-1.06]$ & 0.11 \\
\hline Model 4 & $0.72[0.57-0.90]$ & 0.004 & $0.69[0.49-0.97]$ & 0.03 & $0.75[0.56-1.01]$ & 0.05 \\
\hline Model 5 & $0.79[0.64-0.97]$ & 0.02 & $0.74[0.54-1.02]$ & 0.07 & $0.81[0.61-1.08]$ & 0.15 \\
\hline \multicolumn{7}{|l|}{ Furosine } \\
\hline Model 1 & $0.61[0.48-0.76]$ & $<0.001$ & $0.54[0.38-0.78]$ & $<0.001$ & $0.66[0.50-0.87]$ & 0.003 \\
\hline Model 2 & $0.62[0.49-0.78]$ & $<0.001$ & $0.53[0.36-0.77]$ & $<0.001$ & $0.70[0.52-0.93]$ & 0.02 \\
\hline Model 3 & $0.75[0.59-0.96]$ & 0.03 & $0.59[0.39-0.90]$ & 0.01 & $0.89[0.65-1.21]$ & 0.44 \\
\hline Model 4 & $0.74[0.57-0.97]$ & 0.03 & $0.57[0.37-0.89]$ & 0.01 & $0.89[0.65-1.22]$ & 0.47 \\
\hline Model 5 & $0.78[0.60-0.99]$ & 0.05 & $0.60[0.39-0.91]$ & 0.02 & 0.94 [0.69-1.28] & 0.69 \\
\hline
\end{tabular}

Model 1: Crude model

Model 2: Model 1+ Age, sex and BMI

Model 3: Model 2+eGFR and proteinuria

Model 4: Model 3 + cardiovascular risk factors (total cholesterol, HDL cholesterol, systolic blood pressure, antihypertensive treatment, smoking (current, ex, or never] and diabetes]

Model 5: Model $3+$ transplantation related factors (donor type, total dialysis time, time from transplantation to baseline, cold ischemia time, CNI usage, proliferation inhibitor usage and transplantation count]

eGFR was calculated according to the Chronic Kidney Disease Epidemiology formula with plasma creatinine and plasma cystatin $\mathrm{C}$

Proportional hazards assumption was not violated in any of the models healthy donors, the excretion of a wide spectrum of free amino acids, and many of the free PTM metabolites and of the free AGEs of Lys, Arg and Cys. The focus of the present study was on Lys and its AGEs, notably CML, CEL and furosine. In the donors, the median excretion rates were (pro-donation/post-donation) 10.6/7.8 $\mu \mathrm{mol} / 24 \mathrm{~h}$ for CML, 8.06/6.15 $\mu \mathrm{mol} / 24 \mathrm{~h}$ for CEL and 1.63/0.89 $\mu \mathrm{mol} / 24 \mathrm{~h}$ for furosine. The CML-to-CEL molar ratio was 1.32 pre- and 1.27 post-donation. In the KTR, the median excretion rates of CML $(9.2 \mu \mathrm{mol} / 24 \mathrm{~h})$ and CEL $(6.86 \mu \mathrm{mol} / 24 \mathrm{~h})$ were lower compared to those of the donors pre-donation, but higher compared to post-donation. The CML-to-CEL molar ratio was 1.34 , i.e., very close to that of the donors.

Kidney donation resulted in a decrease of the eGFR by $-37 \%$. With the sole exception of CEA, an AGE of Arg, the urinary excretion rates of all other AGEs, PTM metabolites and native amino acids decreased in the range $-24 \%$ to $-62 \%$ (mean $-45 \%$ ). This decrease is of the order of the drop in eGFR in the healthy donors. The diverging effect of CEA $(+11 \%)$ is strange, especially when comparing with CMA (- 29\%), an AGE of Arg as well. Methylglyoxal (MGO) and glyoxal (GO) are the precursors of CEA and CMA, respectively. Presumably, kidney donation may have induced changes in the synthesis of MGO and GO. The latter compounds are excreted in the urine of healthy humans at mean concentrations each of about $500 \mathrm{nM}$ (Ojeda et al. 2014). In serum of healthy humans, the mean MGO and GO concentrations were reported to be about 98 and $150 \mathrm{nM}$, respectively (Dhananjayan et al. 2019).

In the previous KTR cohort (Sotomayor et al. 2019), higher plasma concentrations of CML and CEL were associated with higher risk for cardiovascular and all-cause mortality. In the KTR of the present study, urinary CML and furosine showed the strongest associations: lower CML and lower furosine excretion rates were found to be associated with higher all-cause mortality. In addition, the urinary excretion of furosine was associated with cardiovascular mortality. Such associations were not found 
Table 3 Association of urinary excretion rates of lysine, CML and furosine with graft failure

\begin{tabular}{llc}
\hline & \multicolumn{2}{l}{ Graft failure } \\
\cline { 2 - 3 } & HR per SD increase [95\% CI] & $P$ value \\
\hline Lysine & & \\
Model 1 & $0.92[0.69-1.21]$ & 0.54 \\
Model 2 & $0.87[0.64-1.19]$ & 0.39 \\
Model 3 & $0.89[0.68-1.16]$ & 0.40 \\
Model 4 & $0.93[0.71-1.22]$ & 0.61 \\
Model 5 & $0.89[0.68-1.16]$ & 0.39 \\
CML & & \\
Model 1 & $0.84[0.65-1.07]$ & 0.16 \\
Model 2 & $0.79[0.61-1.02]$ & 0.07 \\
Model 3 & $0.95[0.74-1.23]$ & 0.71 \\
Model 4 & $0.99[0.78-1.29]$ & 0.99 \\
Model 5 & $0.96[0.74-1.24]$ & 0.74 \\
Furosine & & \\
Model 1 & $0.50[0.36-0.68]$ & $<0.001$ \\
Model 2 & $0.44[0.32-0.61]$ & $<0.001$ \\
Model 3 & $0.76[0.54-1.08]$ & 0.13 \\
Model 4 & $0.80[0.57-1.13]$ & 0.21 \\
Model 5 & $0.78[0.55-1.11]$ & 0.16 \\
\hline
\end{tabular}

Model 1: Crude model

Model 2: Model 1+ Age, sex and BMI

Model 3: Model 2+eGFR ${ }^{\mathrm{a}}$ and proteinuria

Model 4: Model 3+cardiovascular risk factors (total cholesterol, HDL cholesterol, systolic blood pressure, antihypertensive treatment, smoking [current, ex, or never] and diabetes)

Model 5: Model 3+transplantation related factors (donor type, total dialysis time, time from transplantation to baseline, cold ischemia time, CNI usage, proliferation inhibitor usage and transplantation count)

a eGFR was calculated according to the Chronic Kidney Disease Epidemiology formula with plasma creatinine and plasma cystatin $\mathrm{C}$

Proportional hazards assumption was not violated in any of the models

for Lys, the common precursor of CML and furosine. In the same KTR cohort, we found that higher plasma concentrations of ADMA, a major PTM metabolite of Arg, were associated with a higher risk for cardiovascular and all-cause mortality (Frenay et al. 2015a), whereas higher urinary excretions of ADMA and its isomer SDMA were associated with a lower risk for mortality (Said et al. $2019 b$ ). By contrast, lower plasma concentrations of homoarginine and higher excretion rates of homoarginine were found to be associated with higher mortality (Frenay et al. 2015b; Kayacelebi et al. 2017). Possibly, PTM metabolites (such as ADMA and SDMA) and AGEs (such as CML) are associated with mortality in KTR in a similar manner, in contrast to homoarginine, taurine and creatine
(Post et al. 2019a, 2019b), presumably due to their further utility in the body.

The biological functions of non-histone proteins modified by post-translation modification and glycation are only little understood. Better understood are low molecular mass free PTM metabolites and the AGEs released by proteolysis from modified proteins. Thus, ADMA is known to inhibit the activity of nitric oxide synthase (NOS) isoforms that convert L-arginine to L-citrulline and nitric oxide (NO), one of the most potent endogenous vasodilators. SDMA is considered not to be an inhibitor of NOS activity, although it has been reported to inhibit the activity of neuronal NOS, albeit less strongly than ADMA (Tsikas et al. 2000). Despite some inconsistencies and unexplained observations, high ADMA and SDMA production and low homoarginine production are generally assumed to be exclusive NO-related causes for cardiovascular morbidity and mortality in diseases of various organs including the heart and the kidneys (Tsikas et al. 2018). Whether the free $N^{\varepsilon}$-mono-, -di-, and -trimethylated Lys metabolites, i.e., MML, DML and TML, respectively, are involved in certain pathways at relevant concentration ranges analogous to ADMA is unknown. In plasma, high TML concentrations were found to predict major adverse cardiovascular events (MACE) in patients with acute or stable coronary artery disease (CAD), but not in acute ischemic stroke (Schwedhelm et al. 2021). In our study, urinary MML behaved similarly to ADMA both in the KTR and in the healthy donors. The biological activity of MML, DML and TML remains to be investigated.

AGEs are assumed to exert their biological activities via their receptor for advanced glycation end-products (RAGE), which exists in two forms, as membrane-bound (mRAGE) and soluble (sRAGE). CML- and CEL-containing synthetic heptapeptides were found to have very high binding affinity constants, which were about 8 times lower compared to the non-glycated peptides ( $87 \mu \mathrm{M}$ vs. $673 \mu \mathrm{M}$ ) (Xue et al. 2011). This observation suggests that the carboxymethyl and carboxyethyl groups of CML and CEL increase the affinity of these AGEs to the V-domain of RAGE. AGEs derived from long-term in vitro glycation of bovine serum albumin (BSA-AGEs, MW 67.8-78.6 kDa) were found to have much higher affinity (about $1 \mu \mathrm{M}$ ) to soluble human RAGE, with glyoxylic acid-glycated BSA being the most affine (about $0.1 \mu \mathrm{M})$ (Valencia et al. 2004).

RAGE has been linked to several chronic diseases, which share that they are thought to result from alterations in the micro- and macrovasculature, together leading to organ damage and ultimately even to organ failure (Gasparotto et al. 2017, 2019). In KTR, AGEs have been hypothesized to play a role in the pathogenesis of cardiovascular disease, i.e., in the initiation and progression of cardiovascular disease. In our previous study, we found that circulating CML and CEL are prospectively associated with long-term risk 
(A) Urinary $\mathrm{CML}$ excretion and all-cause mortality

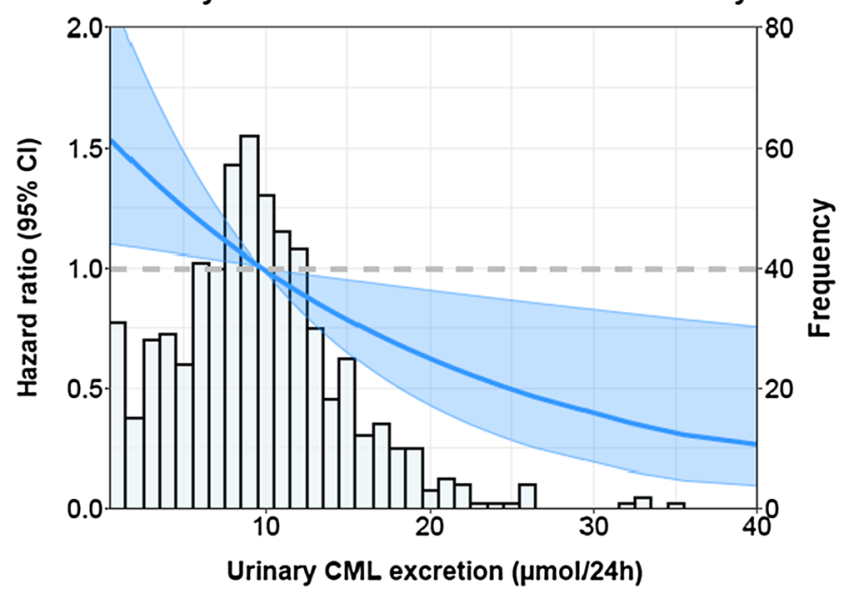

(C)

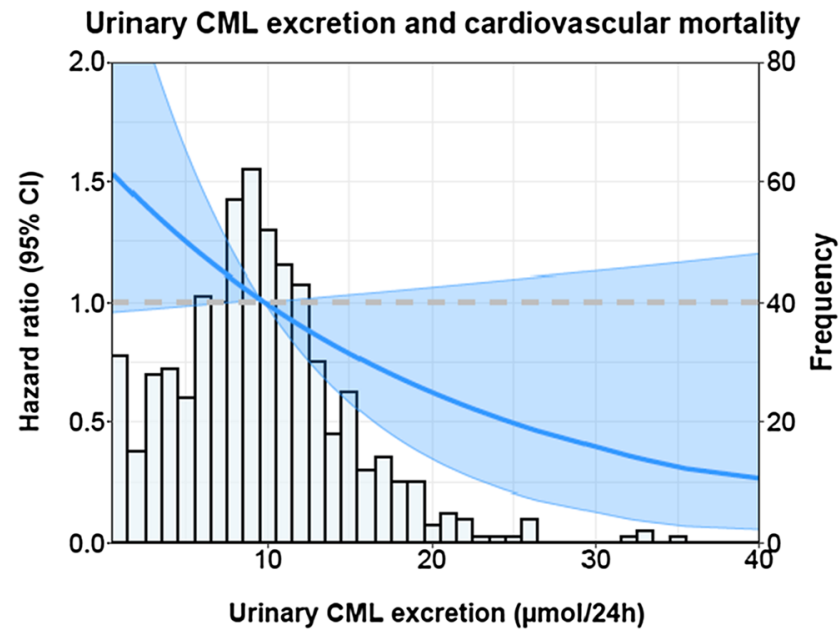

Fig. 1 Associations of urinary excretion rates of A CML and B furosine with all-cause mortality in the KTR, and of C CML and D furosine with cardiovascular mortality. The lines show the adjusted haz-

of cardiovascular mortality in 555 stable KTR (Sotomayor et al. 2019). The present study comprising 630 stable KTR suggests that lower excretion rates of CML and furosine are associated with higher all-cause mortality. In addition, furosine was also associated with cardiovascular mortality. Although we did not measure circulating AGEs in these KTR, the combination of previous findings (Sotomayor et al. 2019), with the observations of the present study suggests that AGEs, notably of Lys (CML, CEL, furosine) and of Arg (CMA), accumulate in the blood because of their insufficient glomerular filtration in the failing kidney. In the mouse, furosine was reported to damage the kidney when administered chronically at very high doses (up to $0.5 \mathrm{~g} /$ $\mathrm{kg}$ ), presumably by triggering ferroptosis, an iron-dependent apoptosis (Li et al. 2020).
(B)

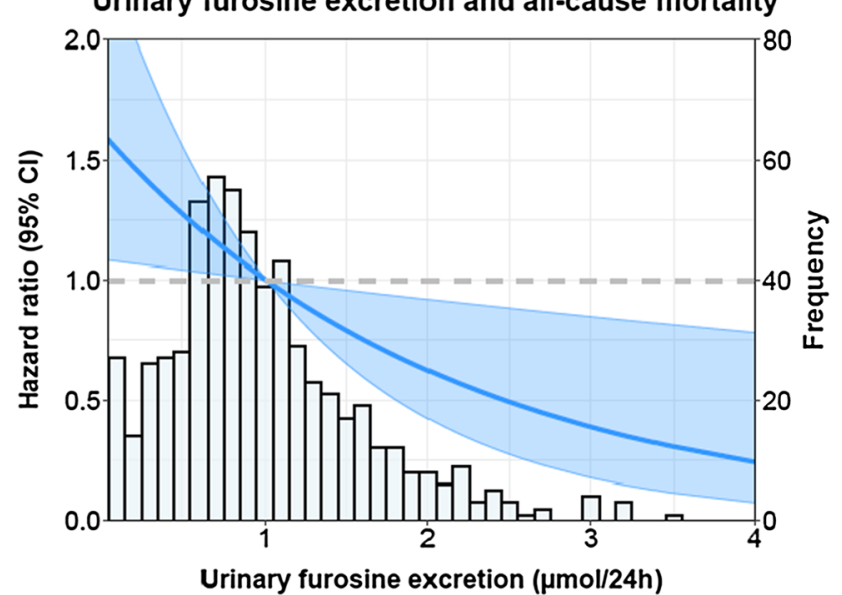

(D)

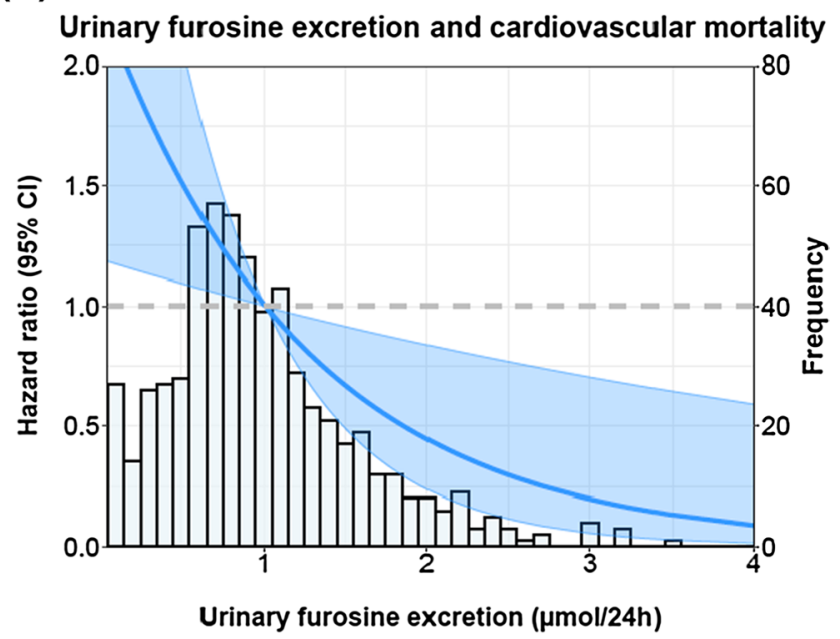

ard ratio (HR) and the shaded area corresponds to the $95 \%$ pointwise confidence interval (CI). The analyses were adjusted for age, sex, BMI, eGFR and proteinuria

In our study, urinary excretion of furosine, but not CML or Lys, was inversely associated with the intake of antihypertensive drugs (St. $\beta-0.34, P=0.005$ ). To our knowledge, there is no report in the literature on such an association in health and disease. Calcium antagonist use was associated inversely with furosine and positively with Lys excretion rates, while diuretics use was strongly inversely associated with Lys. As CML and Lys differ in their structures from furosine only in the furoyl residues (Scheme 1), it could be hypothesized that the furoyl residue of furosine is responsible for these associations. In a type 2 diabetic nephropathy rat model, two anti-hypertensive drugs of different mechanisms of action, i.e., olmesartan and hydralazine, were found to inhibit in vivo formation of protein pentosidine in the kidney and to improve renal damage (Nangaku et al. 2003). Analogous results were observed for various AGEs in vivo 
and in vitro for valsartan (Mil et al. 2021; see also Prasad and Mishra 2017).

It is also interesting to note, that furosine excretion rate was inversely associated with nephropathy, while the excretion rate of CML was associated with prednisolone which is a widely used immunosuppressive in organ transplantations. In our KTR cohort, 627 patients (100\%) received prednisolone, which was positively associated with the CML excretion rate (St. $\beta$ 1.77, $P=0.002$ ). Methylprednisolone has been reported to induce the expression of $R A G E$ genes in primary human keratinocytes (Djerbi et al. 2013). In the (NZB/NZW)F1 mice, intraperitoneal administration of sRAGE was found to alleviate nephritis, and it was as effective as the oral co-administration of mycophenolate and prednisolone (Lee et al. 2013). It has been hypothesized that in the extracellular space sRAGE binds to mRAGE, and by this way reduces the inflammation induced by NF- $\mathrm{KB}$ (Maillard-Lefebvre et al. 2009; Park et al. 2011).

Chemical synthesis of CML requires reductive condensation between Lys and glyoxalate and results in $N, N$-CML due to alkylation of both, the $N^{\alpha}$ and $N^{\varepsilon}$ amine groups of Lys. The first enzymatic synthesis of CML has been reported in 1994 (Miller et al. 1994). This reaction was catalyzed by the NADPH-dependent enzyme $N^{5}$ (carboxyethyl)ornithine synthase (EC 1.5.1.24), which is found in some strains of the lactic acid bacterium Lactococcus lactis.

In healthy Japanese subjects, a major fraction of about 90\% of circulating free CML and CEL was found to be present in erythrocytes at mean concentrations of $0.9 \mu \mathrm{M}$ and $0.2 \mu \mathrm{M}$ (CML-to-CEL molar ratio, 4.5), respectively, as measured by LC-MS/MS (Nomi et al. 2020). The concentration of CML and CEL in blood was found to change after a meal (supplied with about $12.9 \mu \mathrm{mol} \mathrm{CML}$ and $3.3 \mu \mathrm{mol}$ CEL), suggesting an endogenous source of erythrocytic CML and CEL. As aldehydes are the glycation components, it has been investigated whether the genes aldehyde dehydrogenase $2(A L D H 2)$ and 1B type alcohol dehydrogenase $(A D H 1 B)$ are involved in the biosynthesis of CML and CEL with some evidence of a genetic polymorphism in CML metabolism (Nomi et al. 2020). We are not aware whether endogenous AGEs including CML and CEL are formed in humans enzymatically, chemically or both.

Strengths of the present study are the reliable noninvasive simultaneous measurement of free AGEs, PTM metabolites and amino acids in urine samples of the KTR and healthy kidney donors by GC-MS using stable-isotope labeled analogs. In our study, after each urination the container was put immediately into a refrigerator and kept at approximately $4{ }^{\circ} \mathrm{C}$ until the next urination. Under such collection and storage conditions, the AGEs measured in the present study are stable for at least 3 days in human and rat urine (Baskal et al. 2021a, 2021b). To the best of our knowledge, there is no need for stabilization of AGEs in urine or even in blood as demonstrated for CML and CEL (Hull et al. 2013). Obviously, AGEs are chemically and metabolically stable in urine and blood. Further strengths of our study are the large sample size of this well-defined cohort, the long follow-up and the collection of a wide variety of demographical and laboratory parameters allowing adjustment for many potential confounders. Nonetheless, the study limitations also need to be considered. Statistical significance in observational studies by nature does not confirm biological significance. It is unknown whether the relations between AGEs and PTM excretion rates and mortality are causal or associative. In addition, our study population consisted predominantly of Caucasian individuals, which precludes us from extrapolation of our results to populations of other ethnicities. Furthermore, the possibility of residual confounding remains a possibility. In our study, we did not measure the glycemic load of KTR and healthy donors. Yet, in previous large study, glycemic load was not associated with urinary CML or CEL (Maasen et al. 2019).

\section{Conclusion}

Lower excretion rates of CML and furosine, but not of their common precursor Lys, are associated with higher all-cause mortality. In addition, lower excretion rate of furosine is associated with higher cardiovascular mortality in KTR. In the healthy donors of the study, kidney donation is associated with considerable decrease of the excretion rates of almost all amino acids, AGEs and PTM metabolites. The results of the present study suggest that renal excretion of modified and non-modified amino acids is altered in KTR compared to healthy kidney donors. The different associations of furosine with diabetic nephropathy and with the administration of anti-hypertensive drugs, and the association of CML with the intake of the immunosuppressant prednisolone warrants further in vitro and in vivo investigations. Next kidney transplantation studies should include measurements of sRAGE and mRAGE in donors and recipients.

Supplementary Information The online version contains supplementary material available at https://doi.org/10.1007/s00726-021-03091-8.

Acknowledgements This work was supported by Grants from the Dutch Kidney Foundation (NSN C08-2254, P13-114), by COST Action BM1005: ENOG: European Network on Gasotransmitters (www.gasot ransmitters.eu) and by the Top Institute Food and Nutrition (A-1003). This study was based on the TransplantLines Food and Nutrition Biobank and Cohort Study (TxL-FN), which was funded by the Top Institute Food and Nutrition of the Netherlands (grant A-1003). The study is registered at clinicaltrials.gov under number NCT02811835. 
Funding Open Access funding enabled and organized by Projekt DEAL. Open Access funding enabled and organized by Project DEAL. Top Institute Food and Nutrition of the Netherlands (grant A-1003).

\section{Declarations}

Conflict of interest All authors report no conflicts of interest.

Ethical statement The Institutional Review Board approved the study protocol (METc 2008/186) which was in adherence to the Declaration of Helsinki.

Open Access This article is licensed under a Creative Commons Attribution 4.0 International License, which permits use, sharing, adaptation, distribution and reproduction in any medium or format, as long as you give appropriate credit to the original author(s) and the source, provide a link to the Creative Commons licence, and indicate if changes were made. The images or other third party material in this article are included in the article's Creative Commons licence, unless indicated otherwise in a credit line to the material. If material is not included in the article's Creative Commons licence and your intended use is not permitted by statutory regulation or exceeds the permitted use, you will need to obtain permission directly from the copyright holder. To view a copy of this licence, visit http://creativecommons.org/licenses/by/4.0/.

\section{References}

Baskal S, Bollenbach A, Mels C, Kruger R, Tsikas D (2021a) Development and validation a GC-MS method for the simultaneous measurement of amino acids, PTM metabolites and AGEs in human urine and application to the bi-ethnic ASOS study with special emphasis to lysine. Amino Acids 1:1. https://doi.org/10. 1007/s00726-021-03031-6

Baskal S, Büttner P, Werner S, Besler C, Lurz P, Thiele H, Tsikas D (2021b) Profile of urinary amino acids and their post-translational modifications (PTM) including advanced glycation end-products (AGEs) of lysine, arginine and cysteine in lean and obese ZSF1 rats. Amino Acids. https://doi.org/10.1007/s00726-021-03042-3

Baumann M, Caron M, Schmaderer C, Schulte C, Viklicky O, von Weyhern CW, Lutz J, Heemann U (2008) Renal N(epsilon)-carboxymethyllysine deposition after kidney transplantation. Transplantation 86(2):330-335

Busch M, Franke S, Müller A, Wolf M, Gerth J, Ott U, Niwa T, Stein G (2004) Potential cardiovascular risk factors in chronic kidney disease: AGEs, total homocysteine and metabolites, and the C-reactive protein. Kidney Int 66(1):338-347

Busch M, Göbert A, Franke S, Ott U, Gerth J, Müller A, Stein G, Bitsch R, Wolf G (2010) Vitamin B6 metabolism in chronic kidney disease-relation to transsulfuration, advanced glycation and cardiovascular disease. Nephron Clin Pract 114(1):c38-46

Crowley LE, Johnson CP, McIntyre N, Fluck RJ, McIntyre CW, Taal MW, Leung JC (2013) Tissue advanced glycation end product deposition after kidney transplantation. Nephron Clin Pract 124(1-2):54-59

Dhananjayan K, Irrgang F, Raju R, Harman DG, Moran C, Srikanth V, Münch G (2019) Determination of glyoxal and methylglyoxal in serum by UHPLC coupled with fluorescence detection. Anal Biochem 573:51-66

Djerbi N, Dziunycz PJ, Reinhardt D, Iotzova-Weiss G, Hafner J, Läuchli S, French HGFL (2013) Influence of cyclosporin and prednisolone on RAGE, S100A8/A9, and NFkB expression in human keratinocytes. JAMA Dermatol 149(2):236-237

Franke S, Müller A, Sommer M, Busch M, Kientsch-Engel R, Stein G (2003) Serum levels of total homocysteine, homocysteine metabolites and of advanced glycation end-products (AGEs) in patients after renal transplantation. Clin Nephrol 59(2):88-97

Frenay AR, van den Berg E, de Borst MH, Beckmann B, Tsikas D, Feelisch M, Navis G, Bakker SJ, van Goor H (2015a) Plasma ADMA associates with all-cause mortality in renal transplant recipients. Amino Acids 47:1941-1949

Frenay AR, Kayacelebi AA, Beckmann B, Soedamah-Muhtu SS, de Borst $\mathrm{MH}$, van den Berg E, van Goor H, Bakker SJ, Tsikas D (2015b) High urinary homoarginine excretion is associated with low rates of all-cause mortality and graft failure in renal transplant recipients. Amino Acids 47:1827-1836

Gasparotto J, Girardi CS, Somensi N, Ribeiro CT, Moreira JCF, Michels M, Sonai B, Rocha M, Steckert AV, Barichello T, Quevedo J, Dal-Pizzol F, Gelain DP (2017) Receptor for advanced glycation end products mediates sepsis-triggered amyloid- $\beta$ accumulation, Tau phosphorylation, and cognitive impairment. J Biol Chem 293(1):226-244

Gasparotto J, Ribeiro CT, da Rosa-Silva HT, Bortolin RC, Rabelo TK, Peixoto DO, Moreira JCF, Gelain DP (2019) Systemic inflammation changes the site of RAGE expression from endothelial cells to neurons in different brain areas. Mol Neurobiol 56(5):3079-3089

Gross S, van Ree RM, Oterdoom LH, de Vries AP, van Son WJ, de Jong PE, Navis GJ, Zuurman MW, Bierhaus A, Gans RO, Bakker SJ (2007) Low levels of sRAGE are associated with increased risk for mortality in renal transplant recipients. Transplantation 84(5):659-663

Hanff E, Said MY, Kayacelebi AA, Post A, Minovic I, van den Berg E, de Borst MH, van Goor H, Bakker SJL, Tsikas D (2019a) High plasma guanidinoacetate-to-homoarginine ratio is associated with high all-cause and cardiovascular mortality rate in adult renal transplant recipients. Amino Acids 51:1485-1499

Hanff E, Ruben S, Kreuzer M, Bollenbach A, Kayacelebi AA, Das AM, von Versen-Höynck F, von Kaisenberg C, Haffner D, Ückert S, Tsikas D (2019b) Development and validation of GC-MS methods for the comprehensive analysis of amino acids in plasma and urine and applications to the HELLP syndrome and pediatric kidney transplantation: evidence of altered methylation, transamidination, and arginase activity. Amino Acids 51(3):529-547

Hartog JW, Smit AJ, van Son WJ, Navis G, Gans RO, Wolffenbuttel BH, de Jong PE (2004) Advanced glycation end products in kidney transplant patients: a putative role in the development of chronic renal transplant dysfunction. Am J Kidney Dis 43(6):966-975

Hartog JW, de Vries AP, Lutgers HL, Meerwaldt R, Huisman RM, van Son WJ, de Jong PE, Smit AJ (2005) Accumulation of advanced glycation end products, measured as skin autofluorescence, in renal disease. Ann NY Acad Sci 1043:299-307

Hartog JW, de Vries AP, Bakker SJ, Graaff R, van Son WJ, van der Heide JJ, Gans RO, Wolffenbuttel BH, de Jong PE, Smit AJ (2006) Risk factors for chronic transplant dysfunction and cardiovascular disease are related to accumulation of advanced glycation end-products in renal transplant recipients. Nephrol Dial Transplant 21(8):2263-2269

Heidland A, Sebeková K, Frangiosa A, De Santo LS, Cirillo M, Rossi F, Cotrufo M, Perna A, Klassen A, Schinzel R, De Santo NG (2004) Paradox of circulating advanced glycation end product concentrations in patients with congestive heart failure and after heart transplantation. Heart 90(11):1269-1274

Hricik DE, Schulak JA, Sell DR, Fogarty JF, Monnier VM (1993) Effects of kidney or kidney-pancreas transplantation on plasma pentosidine. Kidney Int 43(2):398-403 
Hricik DE, Wu YC, Schulak A, Friedlander MA (1996) Disparate changes in plasma and tissue pentosidine levels after kidney and kidney-pancreas transplantation. Clin Transplant 10(6 Pt 1):568-573

Hull GLJ, Woodside JV, Ames JM, Cuskelly GJ (2013) Validation study to compare effects of processing protocols on measured $\mathrm{N}(\varepsilon)$-(carboxymethyl)lysine and $\mathrm{N}(\varepsilon)$-(carboxyethyl)lysine in blood. J Clin Biochem Nutr 53(3):129-133

Kalousová M, Brabcová I, Germanová A, Jáchymová M, Matl I, Mestek O, Bandúr S, Zima T, Viklický O (2009) RAGE polymorphisms, renal function and histological finding at 12 months after renal transplantation. Clin Biochem 42(4-5):347-352

Kayacelebi AA, Minović I, Hanff E, Frenay AS, de Borst MH, Feelisch M, van Goor H, Bakker SJL, Tsikas D (2017) Low plasma homoarginine concentration is associated with high rates of all-cause mortality in renal transplant recipients. Amino Acids 49:1193-1202

Lee SW, Park KH, Park S, Kim JH, Hong SY, Lee SK, Choi D, Park YB (2013) Soluble receptor for advanced glycation end products alleviates nephritis in (NZB/NZW)F1 mice. Arthritis Rheum 65(7):1902-1912

Li H, Yang H, Li P, Li M, Yao Q, Min L, Zhang Y, Wang J, Zheng N (2020) Maillard reaction products with furan ring, like furosine, cause kidney injury through triggering ferroptosis pathway. Food Chem 319:126368

Liu X, Liu K, Wang Z, Liu C, Han Z, Tao J, Lu P, Wang J, Wu B, Huang Z, Yin C, Gu M, Tan R (2015) Advanced glycation end products accelerate arteriosclerosis after renal transplantation through the AGE/RAGE/ILK pathway. Exp Mol Pathol 99(2):312-319

Maasen K, van Greevenbroek MMJ, Scheijen JLJM, van der Kallen CJH, Stehouwer CDA, Schalkwijk CG (2019) High dietary glycemic load is associated with higher concentrations of urinary advanced glycation endproducts: the Cohort on Diabetes and Atherosclerosis Maastricht (CODAM) Study. Am J Clin Nutr 110(2):358-366

Maillard-Lefebvre H, Boulanger E, Daroux M, Gaxatte C, Hudson BI, Lambert M (2009) Soluble receptor for advanced glycation end products: a new biomarker in diagnosis and prognosis of chronic inflammatory diseases. Rheumatology (oxford) 48(10):1190-1196

Mil KM, Gryciuk ME, Pawlukianiec C, Żendzian-Piotrowska M, Ładny JR, Zalewska A, Maciejczyk M (2021) Pleiotropic properties of valsartan: Do they result from the antiglycooxidant activity? Literature review and in vitro study. Oxid Med Cell Longev 2021:5575545

Miller SP, Donkersloot JA, Thompson J, J, (1994) Enzymatic synthesis and characterization of N(5)-(carboxymethyl)-L-ornithine and N(6)-(carboxymethyl)-L-lysine. Amino Acids 6(2):189-198

Nagai R, Shirakawa J, Fujiwara Y, Ohno R, Moroishi N, Sakata N, Nagai M (2014) Detection of AGEs as markers for carbohydrate metabolism and protein denaturation. J Clin Biochem Nutr 55(1):1-6

Nangaku M, Miyata T, Sada T, Mizuno M, Inagi R, Ueda Y, Ishikawa N, Yuzawa H, Koike H, De Strihou CV, Kurokawa K (2003) Antihypertensive agents inhibit in vivo the formation of advanced glycation end products and improve renal damage in a type 2 diabetic nephropathy rat model. J Am Soc Nephrol 4(5):1212-1222

Nomi Y, Kudo H, Miyamoto K, Okura T, Yamamoto K, Shimohiro H, Kitao S, Ito Y, Egawa S, Kawahara K, Otsuka Y, Ueta E (2020) Free advanced glycation end product distribution in blood components and the effect of genetic polymorphisms. Biochimie 179:69-76

Ojeda AG, Wrobel K, Corrales Escobosa AR, Garay-Sevilla ME, Wrobel K (2014) High-performance liquid chromatography determination of glyoxal, methylglyoxal, and diacetyl in urine using 4-methoxy-o-phenylenediamine as derivatizing reagent. Anal Biochem 449:52-58

Park S, Yoon SJ, Tae HJ, Shim CY (2011) RAGE and cardiovascular disease. Front Biosci (landmark Ed) 16:486-497

Post A, Said MY, Gomes-Neto AW, van der Krogt J, de Blaauw P, Berger SP, Geleijnse JM, Borgonjen K, van den Berg E, van Goor H, Rimbach G, Kema IP, Tsikas D, Heiner-Fokkema MR, Bakker SJL (2019a) Urinary taurine excretion and risk of late graft failure in renal transplant recipients. Nutrients 11(9):2212

Post A, Tsikas D, Bakker SJL (2019b) Creatine is a conditionally essential nutrient in chronic kidney disease: a hypothesis and narrative literature review. Nutrients 11(5):1044

Post A, Bollenbach A, Bakker SJL, Tsikas D (2021) Whole-body arginine dimethylation is associated with all-cause mortality in adult renal transplant recipients. Amino Acids 53(4):541-554

Prasad K, Mishra M (2017) Do advanced glycation end products and its receptor play a role in pathophysiology of hypertension? Int J Angiol 26(1):1-11

Rabbani N, Thornalley PJ (2020) Reading patterns of proteome damage by glycation, oxidation and nitration: quantitation by stable isotopic dilution analysis LC-MS/MS. Essays Biochem 64(1):169-183

Said MY, Douwes RM, van Londen M, Minović I, Frenay AR, de Borst MH, van den Berg E, Heiner-Fokkema MR, Kayacelebi AA, Bollenbach A, van Goor H, Navis G, Tsikas D, Bakker SJL (2019a) Effect of renal function on homeostasis of asymmetric dimethylarginine (ADMA): studies in donors and recipients of renal transplants. Amino Acids 51:565-575

Said MY, Bollenbach A, Minović I, van Londen M, Frenay AR, de Borst MH, van den Berg E, Kayacelebi AA, Tsikas D, van Goor H, Navis G, Bakker SJL (2019b) Plasma ADMA, urinary ADMA excretion, and late mortality in renal transplant recipients. Amino Acids 51:913-927

Schiel R, Franke S, Busch M, Müller A, Fleck C, Müller UA, Braun A, Stein G (2003) Effect of smoking on risk factors for cardiovascular disease in patients with diabetes mellitus and renal insufficiency. Eur J Med Res 8(7):283-291

Schwedhelm E, von Lucadou M, Peine S, Lezius S, Thomalla G, Böger R, Gerloff C, Choe CU (2021) Trimethyllysine, vascular risk factors and outcome in acute ischemic stroke (MARK-STROKE). Amino Acids 53(4):555-561

Sibbersen C, Johannsen M (2020) Dicarbonyl derived post-translational modifications: chemistry bridging biology and aging-related disease. Essays Biochem 64(1):97-110

Slowik-Zylka D, Safranow K, Dziedziejko V, Ciechanowski K, Chlubek D (2010) Association of plasma pentosidine concentrations with renal function in kidney graft recipients. Clin Transplant 24(6):839-847

Sotomayor CG, Gomes-Neto AW, van Londen M, Gans ROB, Nolte IM, Berger SP, Navis GJ, Rodrigo R, Leuvenink HGD, Schalkwijk CG, Bakker SJL (2019) Circulating advanced glycation endproducts and long-term risk of cardiovascular mortality in kidney transplant recipients. Clin J Am Soc Nephrol 14(10):1512-1520

Stein G, Busch M, Müller A, Wendt T, Franke C, Niwa T, Franke S (2003) Are advanced glycation end products cardiovascular risk factors in patients with CRF? Am J Kidney Dis 41(3 Suppl 1):S52-S56

Tsikas D, Wu G (2015) Homoarginine, arginine, and relatives: analysis, metabolism, transport, physiology, and pathology. Amino Acids 47(9):1697-1702

Tsikas D, Sandmann J, Savva A, Luessen P, Böger RH, Gutzki FM, Mayer B, Frölich JC (2000) Assessment of nitric oxide synthase activity in vitro and in vivo by gas chromatography-mass spectrometry. J Chromatogr B Biomed Sci Appl 742(1):143-153

Tsikas D, Bollenbach A, Hanff E, Kayacelebi AA (2018) Asymmetric dimethylarginine (ADMA), symmetric dimethylarginine (SDMA) 
and homoarginine (hArg): the ADMA, SDMA and hArg Paradoxes. Cardiovasc Diabetol 17(1):1

Valencia JV, Weldon SC, Quinn D, Kiers GH, DeGroot J, TeKoppele JM, Hughes TE (2004) Advanced glycation end product ligands for the receptor for advanced glycation end products: biochemical characterization and formation kinetics. Anal Biochem 324(1):68-78

van den Berg E, Engberink MF, Brink EJ et al (2012) Dietary acid load and metabolic acidosis in renal transplant recipients. Clin J Am Soc Nephrol 7:1811-1818

van den Berg E, Engberink MF, Brink EJ et al (2013) Dietary protein, blood pressure and renal function in renal transplant recipients. Br J Nutr 109:1463-1470

van den Berg E, Pasch A, Westendorp WH et al (2014) Urinary sulfur metabolites associate with a favorable cardiovascular risk profile and survival benefit in renal transplant recipients. J Am Soc Nephrol 25:1303-1312
Xu Z, Liu X, Wang Z, Tao J, Han Z, Gu M, Zhang W, Tan R (2017) Effect of sirolimus on arteriosclerosis induced by advanced glycation end products via inhibition of the ILK/mTOR pathway in kidney transplantation recipients. Eur J Pharmacol 813:1-9

Xue J, Rai V, Singer D, Chabierski S, Xie J, Reverdatto S, Burz DS, Schmidt AM, Hoffmann R, Shekhtman A (2011) Advanced glycation end product recognition by the receptor for AGEs. Structure 19(5):722-732

Publisher's Note Springer Nature remains neutral with regard to jurisdictional claims in published maps and institutional affiliations. 